\title{
Integrity of Political Policy in Village Government During the Implementation of the Covid-19 Pandemic Disaster Mitigation
}

\begin{abstract}
Ayu Febriani ${ }^{*}$, Agus Mahfud Fauzi ${ }^{2}$
${ }^{1}$ Universitas Negeri Surabaya

${ }^{2}$ Universitas Negeri Surabaya

*Corresponding Author. Email: ayu.18021@mhs.unesa.ac.id

ABSTRACT

Integrity is consistency in certain actions. The strength or weakness of integrity is determined by the perpetrator of the action. In this case, the Banyukambang Village Government, Wonoasri District, Madiun Regency is given the authority to have good integrity in mitigating the COVID-19 disaster. This authority is granted in accordance with a Circular which contains an appeal for the extension of restrictions on micro community activities with the One Gate System (OGS) program. The purpose of this study was to determine the integrity of Banyukambang Village's political policies in mitigating the COVID-19 pandemic. This study uses the structural functional theory of Talcott Parsons with a qualitative research approach. The results of the study found that the Integrity of the Banyukambang Village Government implemented Covid-19 mitigation in the One Gate System (OGS) program using a socio-political approach. This approach is carried out to balance the interests between the community and the village government during the Covid-19 pandemic. There are twelve programs that have been successfully established using these two approaches, with the main focus being deliberation on determining social sanctions for violators of the one gate system policy and conducting "Sambatan Panen" to meet the food subsistence needs of the poor during the COVID-19 pandemic. Thus, the number of Covid-19 transmissions in the Banyukambang village decreased and the socio-economic stability of the community remained guaranteed.
\end{abstract}

Keywords: Integrity, Political Policy, Covid-19 Mitigation, Banyukambang Village Government.

\section{INTRODUCTION}

Large-scale social restrictions during the covid19 pandemic impacted the structure of rural life in the social, economic, political, cultural, educational and health fields. The central government and local governments continue to cooperate in reviewing and implementing these social restrictions into a mitigation policy in order to achieve social order.In this case, the participation and integrity of the village government is very important because it interacts directly with its people. HAW Widjaya (2003: 3) defines village government as the organizer of village government and is a subsystem of the national government implementation system. Thus, the village government has a strategic role that is to organize its people for the stability of government development.

On the other side, the interests of the community are the responsibility of the village government[3]. Thus, as long as the community is in an urgent situation that threatens the welfare of its life, the village government as the smallest unit of the village must have autonomy on certain policies to maintain the welfare of its people until the condition of the community begins to stabilize. During the covid-19 pandemic, the participation of the village government in protecting its people is a follow-up to the Circular Letter of the Minister of Villages, Development of Disadvantaged Regions and Transmigration Number 8 of 2020, on Village Response to the covid-19 pandemic that has been established on March 24, 2020.In the regulation, the village government plays a role to socialize, regulate, and establish a new mitigation policy to maintain the welfare of the community by forming a covid-19 Response Village [5].

Policies are formed as projects to achieve the best goals, values and practices of social, economic, cultural and educational affairs.Mitigation is a series of efforts to reduce the risk of disasters or pandemics carried out in the form of physical development or increased knowledge and ability to deal with disaster threats. Thus, mitigation policies can be understood as all actions that can reduce the impact of a disaster, including on readiness and other actions that can reduce the risk of long-term disasters.

In the situation of the covid-19 pandemic, mitigation can be done by increasing knowledge of the dangers of covid-19 and habituation of healthy living of the community. Knowledge will be the power to classify objects derived from human sensing results, namely the ears and eyes. Thus, by increasing human knowledge about disaster alert, mitigation policies can also help the community in responding to all actions that are deliberately done or stimulated 
on them in order to achieve mutual safety.

Each Village Government will implement different mitigation policies in accordance with the development of covid- 19 in their respective regions. As is the case in Sukajaya Village, Sumedang Regency and Maduretno Village, Kediri Regency. These two regions can form a synergistic mitigation policy because it involves the village youth community namely Karang Taruna or "Tunas Muda" in socializing covid-19 disaster mitigation. Therefore, during the covid-19 pandemic the number of social, economic, cultural, and educational problems was low[1][10]. Furthermore, the Lowayu Village Government of Gresik District Shaman District also has a policy that is able to reconstruct the economy of its people through normalization of economic activities while still implementing health protocols [11]. However, because the development of the spread of covid-19 cannot be predicted in each region, local governments must remain vigilant by forming and updating targeted mitigation policies.

As in the Madiun Regency Government which sets mitigation policies in the category of supervision of activities in and out of the community, namely One Gate System (OGS). The establishment of one gate system is taken into account in order to support the extension of the implementation of restrictions on community activities [12]. One Gate System (OGS) is a new form of covid-19 mitigation after the evaluation of the implementation of the first community activity restrictions on January 11-25, 2021 was declared to have failed to reduce the spread of covid-19 [13].

Before implementation of the One Gate System (OGS), the Madiun Regency Government had two mitigation strategies. First, the Task Force Post acceleration handling Covid-19 located in Padepokan Madiun Kampung Pesilat, terminal, and station. The establishment of this post is aimed at facilitating joint monitoring of the development of covid-19 in Madiun Regency to obtain accurate data to evaluate the implementation of social restrictions. Second, the expansion of the medical team consisting of the Health Office, Dolopo and Caruban General Hospital, as well as 26 health centers of Madiun Regency [14].

The One Gate System (OGS) policy was formed by the perception of the Regent of Madiun, Ahmad Damawi, who estimated the transmission of covid-19 in a matter of two weeks to one month. It is expected that with the One gate System (OGS), Madiun Regency which was originally a red zone is considered to be as soon as an orange zone or even a green zone[ 12]. Based on data by the Madiun Regency Cominfo in 2020, many patients are from outside the city and when patients have not been identified they interact with their families. Thus, the increase in covid- 19 cases is strongly influenced by family clusters. The establishment of One Gate System (OGS) is not intended to hurt the community, but to supervise activities in and out of the village to be more neatly organized [15]. One
Gate System (OGS) simultaneously appealed to all areas of Madiun Regency with the Village Government as the main person in charge.

Thus, the village government has a duty to seek change towards social order in its community while implementing the One Gate System (OGS) [10]. An integrity or consistency from the Village Government, namely the Kelurahan must be able to function optimally in implementing new mitigations with the One Gate System (OGS), in order to achieve these goals [11]. By taking the research location in Banyukambang Village, Madiun Regency as one of the areas that managed to enter the orange zone category after implementing the One Gate System (OGS) [16], researchers are interested in researching it by formulating the problem of how the integrity of the Banyukambang Village government's political policy in mitigating the covid pandemic disaster -19 during the implementation of the One Gate System (OGS)?.

\section{METHODS}

This research uses a qualitative research approach with case study methods. The approach was chosen because researchers collect real data from in-depth field studies [17]. Nawawi (1983:64) describes qualitative research approaches focusing on phenomena that are factual, and described descriptively as they are followed by rational and accurate interpretations[ 18]. Research location in Banyukambang Village, Wonoasri Subdistrict, Madiun Regency. The study subjects were determined through purposive sampling which included the village head, two village device staff, and several local communities. Data collection uses primary and secondary sources. Primary sources are obtained from live and online (hybrid) interview and observation data. Secondary sources are obtained from books, articles, journals, ebooks and others.

The collected data was analyzed using Miles and Huberman's analysis model [19]. First, compile fieldnotes. Second, conduct a thorough review of the interview and observation data that has been presented in fieldnotes. Third, data reduction by sorting data by creating abstracts or core summaries. Fourth, perform a unityzing process to categorize data. Fifth, the interpretation of data. Sixth, verify to get the final conclusion. This research legitimacy examination technique uses data triangulation, which consists of source triangulation, data collection technique triangulation, and time triangulation [20]. Source triangulation is used to check primary and secondary data so that findings are not biased. Triangulation of data collection techniques in the form of interviews and observations. Triangulation of data collection time adjusts the deepening of the interview. 


\section{RESULTS AND DISCUSSION}

\subsection{Discussion}

Following up on the Circular Letter of the Minister of Villages, Development of Disadvantaged Regions and Transmigration Number 8 of 2020, on the Village Response of the covid-19 pandemic established since March 24, 2020, regarding the role of the Village Government to socialize, regulate and establish new mitigation policies during the One Gate System (OGS) as a form of covid-19 Response Village, the Banyukambang Village Government immediately took mitigation measures, among others:

a) Formation of Village Volunteer Team; This is the main step taken by the banyukambang village government. The team of village volunteers formed was assigned to different parts despite being in the same organization. The group that is familiarly called "Banyukambang Task Force Team" consists of village devices, village heads, heads of neighboring pillars, village chaperones, cadet corals, extensionists, security guards, indigenous and religious figures, village medical personnel, village health centers, and volunteers (communities), who partner with "Bhabinkamtibmas" and "Babinsa" from the Indonesian Police and National Army who serve in the Banyukambang area. They cooperate cooperatively and intensively in supervising the activities of the people of Banyukambang village, and crack down firmly if health prokes are not done properly. In addition, the covid- 19 task force team will also provide regular counseling for one month to increase the knowledge, sensitivity, and compliance of citizens to always comply and implement health protocols, whether when moving outside or anywhere. Details of this extension include: education on the prevention of covid-19 from the $3 \mathrm{M}$ Movement to the $5 \mathrm{M}$ movement; the collection of vulnerable people who are sick; disinfectant spraying; providing isolation and medical devices; as well as detecting the spread of covid-19 by ensuring there is no crowd.

b) Procurement of Guard Posts at all entrances of Banyukambang Village, by the covid-19 response front group unit team namely village security and volunteers (community), on a rotating basis for 24 hours. They were given the task of supervising and recording the activity in and out of community vehicles at posts located throughout the village in and out of the village. As for the recording of the immigrant population which will later be reported to the chairman of rukun Tetangga to be forwarded to the village head. This is done because currently
Banyukambang village minimizes restrictions on community activities micro. At first, the data collection and reporting was carried out by the village security team who stood guard at the main post of the village. However, it is now tightened by the procurement of the main post in each Chairman of the Neighboring Pillar. Therefore, the supervision and reporting of migrant guests will be carried out by the chairman of rukun Tetangga to the village head. So, the village government is able to carefully record the activity in and out of vehicles and migrant residents through one entrance to the village.

c) Procurement of Medical Devices in every citizen's house, carried out in accordance with the appeal of the Madiun Regent Circular Letter, namely, village funds that have been allocated and updated to adjust the needs of village community health protocol services. Based on the data findings, the procurement of medical devices in Banyukambang village is focused on infrastructure development and the addition of medical devices in every citizen's home. It aims to familiarize the lifestyle of the less healthy people of Banyukambang village to become accustomed to a healthy lifestyle through the provision of medical devices provided as follows:

- A place to wash hands with soap in every house

- Distribution of masks, in accordance with the appeal of the World Health Organization (WHO) so that citizens who want to do activities outside the home must wear masks. The distribution of masks has been carried out regularly since February 2020. Administratively, Banyukambang Village is only able to facilitate the distribution of masks as many as 36 dozen or 436 pieces. To deal with this, the village head took another approach by collaborating the village economic unit (UMKM) and the pkk mothers community of Banyukambang Village to produce masks that were then distributed to their citizens. Thus, the existence of these two actions greatly helps the integrity of the village government in protecting the health of its people during the covid-19 pandemic.

- Distribution of Handsanitizer in public places such as mosques, village halls, schools and One Gate System (OGS) postal posts. Another handanitizer distribution, given to some elderly people who live alone. This is done to prevent the habit of the elderly group of Banyukambang to live a makeshift life even in the midst of a pandemic.

d) Free Posyandu for children and the elderly. This program has been conducted once in every month. There are two focuses of posyandu implementation, namely, going around each 
hamlet to do health checks on toddlers and providing vitamins to the elderly in each local hamlet. Although the implementation is only once a month, posyandu activities will still be available at the available village health centers. So, people who are not the focus of the mobile posyandu will still receive health services at any time.

e) Counseling on Covid-19. The activity is carried out at least 2 times a month with participants taking turns adjusting the invitation letter made by the village. This is done to avoid crowds. Counseling is carried out in 2 ways, namely collaboration between village officials, volunteer teams, and village health teams. Furthermore, counseling is carried out in collaboration between village officials, volunteer teams, and regional health centers.

f) Installation of 5M Banners in every strategic place of the village. This activity is a written socialization in suppressing the spread of COVID-19.

Before the implementation of the One Gate System (OGS) it was recommended to carry out the $3 \mathrm{M}$ process, now it has changed to $5 \mathrm{M}$, namely, wearing masks, washing hands with soap and running water, maintaining distance, staying away from crowds and limiting mobilization and interaction [21].

g) Plangiation, is a concrete manifestation of the front group team of Banyukambang Village to keep up the call for the application of one village entrance or One Gate System (OGS). In this plan, the Banyukambang village task force team made a sign, either made of wood or iron, to cover the sub-road which is the access to the village. This plangiation is the main obligation of every village when implementing the One Gate System (OGS) [15].

h) Spraying Disinfectant. Have done twice in one month. This spraying was carried out by the Banyukambang village "task team" and the local community in public places such as mosques, schools, village offices, posts and self-isolation places.

i) Validation of Covid-19 Affected Family Data. Since February 2021, Banyukambang village has begun to minimize monitoring or supervision of community activities. This monitoring narrowing is at the stage of reporting on residents' daily activities through data from the head of the Neighborhood Association and data from the Command Post. Data findings show that in January there were residents who came from Bali but escaped the supervision of the Command Post. However, thanks to the alertness and cooperation of the community in the observance of the implementation of the prokes during the pandemic, it was finally resolved. In addition, the validation of the data on affected families is also related to the distribution of village fund assistance. Village officials are assisted by the head of the community unit, neighborhood unit, and posyandu to understand the socio-economic conditions of the community. Although there are still discrepancies, such as double registration numbers, residents who have moved, and residents who have died. Thus, this becomes a challenge for the village government to ensure data validation so that assistance can be channeled properly.

j) Implementation of the Banyukambang Village Cash Intensive Program. Since 2020, the central government has mandated changes to the Village Revenue and Expenditure Budget (APBDes) to focus more on program activities that deal with Covid-19. Based on a statement from Mr. Senggono as the secretary of the Banyukambang village, the Central and Regency Governments through the Community and Village Empowerment Service, Regional Inspectors and Camats, it is recommended to always supervise and foster budgets that can be allocated on target. Thus, the village government can optimize the prevention of the spread of COVID-19. Then, the realization of the Cash Intensive Work in Banyukambang Village is through the establishment of a village business that collaborates with the village economic unit (UMKM) and the women's group (PKK). This effort will help buy and sell some of the community's works during the covid- 19 pandemic.

k) Changes in the village budget in the Village Cash Assistance (BLTD). Starting in 2020, village funds will go directly to village accounts. In Banyukambang village, village funds are allocated more for assistance and social services for families or communities affected by COVID-19. In the administrative approach, the target recipients of the Banyukambang Village Cash Direct Assistance (BLTD) are poor families, and have been registered in the Social Welfare Integrated Data (DTKS), among others, have lost their jobs, have chronic diseases, do not include $\mathrm{PKH}$ and BPNT recipients, are not holders of preemployment cards, and those who are really poor. It's different in Banyukambang village. The social sensitivity of the village government in seeing the rate of poverty in its community encourages it not to be limited to the budgeted APBN approach. This is because programs that are driven using the APBN approach will not budget for assistance to the poor who are categorized as unregistered people [23]. There are two ways that the village government does in ensuring the survival of its people, namely: First, changing the nominal amount of 
assistance from Rp. 500,000 to Rp. 300,000 for each poor family. A total of Rp 200,000 will be collected to be distributed fairly and equitably to the poor who are categorized as unregistered people [23]. Second, carry out the "Sambatan Panen" action on their farmer groups to set aside the harvest of rice or vegetables to the poor. Thus, the food needs of the poor can be met during the COVID-19 pandemic.

1) Open deliberation on sanctions for violating health protocols and violating the One Gate System (OGS) between the village government and the village community. The deliberation mechanism is through a small forum in the village hall which is attended by village communities who want to report or take direct action on sanctions that will be given by violators. This forum will also involve village religious leaders to act as intermediaries in charge of aligning the rationality of sanctions from the community with applicable village laws and customs.

\subsection{Discussion}

The collaboration between the community and the Village Government in Banyukambang Village is a dialectical relationship between agents and village structures that shape the policy to mitigate the spread of COVID-19. The people of Banyukambang village are the measure of the evaluation of policy programs carried out by the village government in maintaining the safety of their people during the covid-19 pandemic. Based on data findings, mitigation policy programs have been welcomed with active participation by the community. Thus, the village government together with the community can function properly in a unified social system to mitigate the COVID-19 disaster. Although the One Gate System (OGS) policy implemented limits community activities, the fact is that it can function to establish community order in suppressing the spread of COVID- 19 in Banyukambang village.

In the book "The Present Status of "Structural-Functional" Theory In Sociology" (1975) which discusses Parsons' structuralfunctional theory, the application of policies by collaborating political and social approaches in society can be understood as a unified system in an interdependent society. between one another, to create order and dependence between the components and their environment [24]. Furthermore, Parson (1975) also states that society is like a set of systems whose parts are interconnected. For example, society can function properly without social interaction [25]. Every time there is a change in one part, it will affect and cause instability that will create changes in other parts.
Each Banyukambang village community is integrated from the results of a mutual agreement, and the agreement is elemental and related to the values contained in the agreement [26]. This value is used because they have the ability to overcome differences and problems that exist in their lives during the covid-19 pandemic. So, from this statement it can be stated that society is a functionally integrated system and is interconnected in a balanced way between one another [27]. Parsons has 4 absolute requirements that must exist so that the system in society can have good integrity, namely:

- Adaptation: The system adapts to the environment according to its needs to avoid and stay away from crisis situations.

- Goal attainment: The system defines how to achieve its main goals.

- Integration (integration): The system regulates the relationship between its component parts, as well as the relationship between the three other important functions, namely A, G, and I.

- Pattern maintenance (latency): The system must try to improve, equip, and maintain a culture that accommodates motivation [28].

In this case, compliance and community behavior is a reflection of the firmness and responsiveness of social, cultural, religious, and political institutions in that society. The Banyukambang village government as a socio-political institution and the person in charge of the formulation of mitigation policies has the power to seek social order as long as it is under certain conditions, with policy programs that are formed according to the needs of the people's lives.

Socially, the community (village) itself can appear as an actor as well as a network of social groups that are mutually organized and interact in a rather regular way, because there is a set of certain rules and values that are shared and believed in [29]. Thus, all public participation in any events, changes, or regulations that are present and affect people's lives will be functional for the community. The affirmation of restrictions on community activities through the One Gate System (OGS) is a community need because all structures will be functional and their functioning can be assessed. This is evidenced by the presence of changes in the distribution of Covid-19 which has decreased through mitigation policies carried out by involving a social-community approach in addition to the prevailing political 
approach. So that the people of Banyukambang village can regain social balance after 2 months of implementing the One Gate System (OGS).

\section{CONCLUSION}

The integrity of the Banyukambang Village Government's political policy in mitigating the COVID-19 disaster has gone well. The policy is carried out by combining two political and socialsocial approaches into various programs that include active participation from the people of Banyukambang Village. So, it can be stated that the Banyukambang village government has gradually succeeded in changing the community's principle of the one gate system (OGS) into a new motivation in suppressing the spread of COVID19. This stage is in the 12 mitigation programs that have been successfully produced by them, including: (1) the formation of a team of village volunteers, (2) the provision of guard posts at all entrances and exits of the Banyukambang village by the team of the Covid-19 response front group, namely village security and volunteers. (community) in rotation for 24 hours, (3) procurement of medical devices in every resident's house, (4) free posyandu for children and the elderly, (5) counseling on covid19, (6) installation of $5 \mathrm{~m}$ banners in every strategic place of the village, (7) plangiation, (8) spraying disinfectants, (9) validation of data on families affected by COVID-19, (10) implementation of the Banyukambang Village cash-intensive program, (11) changes in the allocation of social assistance driven by the state budget approach and social community approach through "Sambatan Panen" for the poor, unregistered people, and (12) open deliberation on sanctions for violating health protocols between the village government and village communities.

\section{AUTHORS CONTRIBUTIONS}

All authors conceived and designed this study. All authors contributed to the manuscript revisions and aprroved the final version of manuscript and agree to be held acountable for the content therein.

\section{ACKNOWLEDGMENT}

Along with the completion of this research, the authors would like to thank for the availability of time and the trust that has been given by all informants to the author. Mainly, the authors would like to thank the Banyukambang Village Government for being willing to take the time to conduct interviews with the author. Thus, research can be carried out and completed on time.

\section{REFERENCES}

[1] A. N. Hidayati, "Upaya Pemerintah Desa Dalam Menanggapi Dampak Covid-19 Di Desa Sukajaya Kecamatan Sumedang Selatan Kabupaten Sumedang," J. Polit. Pemerintah. Dharma Praja, vol. 13, no. 1, pp. 14-35, 2020, doi: 10.33701/jppdp.v13i1.1044.

[2] H. Widjaja, Otonomi Desa Merupakan Otonomi Yang Asli Bulat dan Utuh. Jakarta: Pt. Raja Grafaindo Persada, 2005.

[3] N. N. Pujaningsih and I. G. A. A. D. Sucitawathi, "Penerapan Kebijakan Pembatasan Kegiatan Masyarakat (Pkm) Dalam Penanggulangan Wabah Covid-19 Di Kota Denpasar," Moderat, vol. 6, no. 3, pp. 458-470, 2020.

[4] R. B. J. Maramis and K. W. Wicaksono, "Integritas Perilaku Kepemimpinan Publik Walikota Bandung," Otoritas J. Ilmu Pemerintah., vol. 7, no. 1, p. 28, 2017, doi: 10.26618/ojip.v7i1.394.

[5] Menteri Desa, Surat Edaran Menteri Desa, Pembangunan Daerah Tertinggal dan Transmigrasi Nomor 8 tahun 2020, tentang Desa Tanggap pandemic covid-19. 2020.

[6] Zainal, "Dinamika Kebijakan Pemerintahan Desa Di Indonesia Dari Masa Ke Masa (Studi Tahun 1979-2015)," J. TAPIs, vol. 12, 2016.

[7] P. D. Jmison Pike, Tiffany Bogich, Sarah Elwood, David C.Finnoff, "Economic optimization of a global strategy to address the pandemic threat," Proc. Natl. Acad. Sci. U. S. A., vol. 111, no. 52, pp. 18519-18523, 2014 , doi:

10.1073/pnas.1412661112.

[8] A. Puspitasari and H. Rahman, "Pelatihan Mitigasi Bencana Dalam Menghadapi Pandemi Covid-19 Di Dusun Kalebajeng Kelurahan Kalebajeng Kecamatan Bajeng ...," Community ..., vol. 2, no. 1, pp. 32- 36, 2021, [Online]. Available: https://journal.universitaspahlawan. ac.id/index.php/cdj/article/view/141 0 .

[9] N. Y and H. F. Etri, "Mencegah Penularan Virus Corona," J. Abdimas Saintika, vol. 2 Nomor 1, 2020.

[10] D. Ertiana, M. Ulfa, N. Widya, and Y. Prastiwi, "Peningkatan Peran Serta Masyarakat Dalam Maduretno Kecamatan Papar Kabupaten Kediri," J. Pengabdi. dan Pemberdaya. Masy., vol. 02, no. November, pp. 23-33, 2020. 
[11] D. Suliswati and F. Razi, "Kebijakan Pemerintah Desa Lowayu Kecamatan Dukun Kabupaten Gresik Dalam Rekonstruksi Ekonomi Pasca Pandemi Covid-19," Pros. Penelit. dan Pengabdi. Kpd. Masy., vol. 7, no. 2, p. 348, 2020, doi: 10.24198/jppm.v7i2.28977.

[12] M. Al Alawi, "Kebijakan One Gate System Diklaim Turunkan Zonasi Covid19 di Madiun dari Merah ke Oranye," Kompas.com, 2021. https://regional.kompas.com/read/2 021/02/11/07311031/kebijakan-one- gatesystem-diklaim-turunkan- zonasi-covid19-di-madiun- dari?page $=$ all.

[13] M. Al Alawi, "Kasus Kematian Covid-19 Terjadi Setiap Hari, Bupati Madiun Terapkan Satu Desa Satu Pintu Masuk," Kompas.com, 2021. https://regional.kompas.com/read/2 021/02/04/22364651/kasus- kematiancovid-19-terjadi-setiap- hari-bupatimadiun-terapkan-satu- desa?page $=$ all.

[14] S. Harianto, "Kabupaten Madiun Zona Merah, Ada Posko Covid-19 di Terminal dan Stasiun," detikNews.com, 2020. https://news.detik.com/berita-jawa-timur/d4961931/kabupaten- madiun-zona-merahada-posko- covid-19-di-terminal-danstasiun.

[15] M. Haryono, "One Gate System Bukan untuk Sengsarakan Warga," rri.co.id, 2021. https://rri.co.id/madiun/daerah/9720 67/one-gate-system-bukan-untuksengsarakanwarga?utm_source=news_main\&ut m_medium=internal_link\&utm_ca mpaign=General Campaign.

[16] Dinas Sosial, "Persebaran Covid-19 di Kabupaten Madiun Tahun 2021," Madiun, 2021.

[17] Mundir, Metode Penelitian Kualitatif dan Kuantitatif. 2013.

[18] H. H. Nawawi, Metode Penelitian Deskriptif. Yogyakarta: Gajah Mada University Press, 1983.

[19] M. B. Miles, A. M. Huberman, and J. Saldaria, Qualitative Data Analysis: A Methode Sourcebook, Edisi 3. United States of America: SAGE Publications, 2014.

[20] Sugiyono, "Metode Penelitian Kuantitatif, Kualitatif, R\&D,” Bandung:IKAPI, 2016.

[21] RUPBASAN WONOSARI, "Tidak Cukup 3M untuk Protokol Kesehatan Covid-19, tetapi

$5 \mathrm{M}, "$ rupbasanwonosari.kemenkumham.g o.id, 2021.

http://rupbasanwonosari.kemenkum ham.go.id/index.php/berita- utama/tidakcukup-3m-untuk- protokol-kesehatancovid-19-tetapi- 5m.

[22] K. RI, "Pemerintah Pusat Koordinasikan Realokasi dan Anggaran Daerah untuk Dukung Penanganan Covid-19," kemenkeu.go.id, 2020. https://www.kemenkeu.go.id/publik asi/siaran-pers/siaran-pers- pemerintahpusat-koordinasikan- realokasi-dananggaran-daerah- untuk-dukungpenanganan-covid- $19 /$.

[23] R. Yasni, H. Yulianto, and D. J. Anggaran, "Peran Belanja Modal dan Belanja Bantuan Sosial Pemerintah Daerah Terhadap Ketimpangan Pendapatan di Indonesia," vol. 4, no. 1, pp. 39-63, 2016.

[24] T. Parsons, The Present Status of "Structural-Functional" Theory In Sociology. New York: The Pass Perss, 1975.

[25] M. C. B. Umanailo, "Talcot Parson and Robert K Merton,” no. October, 2019, doi: 10.31219/osf.io/9pmt3.

[26] M. C. B. Umanailo, "Talcot Parson and Robert K Merton," 2019, doi: 10.31219/osf.io/9pmt3.

[27] P. Sorokin and M. P. Richard, "Social and Cultural Dynamics: A Study of Change in Major Systems of Art, Truth, Ethics, Law and Social Relationships," Soc. Cult. Dyn. A Study Chang. Major Syst. Art, Truth, Ethics, Law Soc. Relationships, pp. 1-719, 1970, doi: 10.4324/9781315129433.

[28] G. R. dan D. J. Goodman, Teori Sosiologi: Dari Teori Sosiologi Klasik Sampai Perkembangan Mutakhir. Yogyakarta: Kreasi Wacana, 2008.

[29] A. Giddens, The Constitution of Society: Teori Strukturasi untuk Analisis Sosial. Terjemahan. Pasuruan: Pedati, 2003. 